\title{
Reading 'Attār's Elāhināma as Sufi Practical Ethics: Between Genre, Reception, and Muslim and Christian Audiences
}

\author{
Ghazzal Dabiri \\ Ghent University \\ ghazzal.dabiri@ugent.be
}

\begin{abstract}
This paper seeks to contribute to the field of reception and audience studies by analyzing 'Attār's Elāhināma. Little studied, the Elāhināma offers an opportunity to understand better 'Attār's attitudes towards socio-religious issues, as well as the types of audiences that the text seeks, how it addresses them, and what possible aims it has. The paper argues that the Elähināma mobilizes the formal characteristics of practical ethics and mirrors while disrupting them at the level of meaning towards its own aims, namely, a just society grounded in the tenets of Sufism, for a broad, non-specialized audience, which also includes Christians and Muslims. The paper analyzes and discusses not only the structure of the overall text, but also the first story, the "Tale of the Virtuous Woman," which sets the tone. This story is an interesting case since it resembles the way that lives of female Byzantine Christian saints are constructed. It thus offers an opportunity to comment on the itinerant nature of narratives across Eurasia and more specifically the types of tales circulating in medieval eastern Iran.
\end{abstract}

\section{Keywords}

'Attār - Elāhināma - Sufi practical ethics - audience reception

* I would like to acknowledge and thank the European Research Council (project number 337344) for the opportunity to research and write this article. 
The Elähināma (Book of the Divine) is one of the principle works of the influential Sufi poet and author, Farid al-Din 'Attār (d. c. 1221). It is the tale of a caliph whose six sons are accomplished kings in their own right, yet who still require his spiritual guidance. One day, the caliph gathers his sons to ask them about their goals, which range from love to ultimate power in its variegated manifestations. Disappointed by his sons' worldly ambitions, the caliph tries to temper their desires by offering them advice. When they resist his counsel and counter his arguments, he narrates a series of tales to support his case, until one-by-one they are convinced. The tales feature a wide variety of stock characters and popular mythical, legendary, and historical figures drawn from the literary and cultural well of medieval Islamicate society. Lessons on love and faith abound as the spirit of Sufism courses through each tale, encouraging the sons to seek deeper spiritual truths through self-knowledge and awareness of the divine. ${ }^{1}$ As such, the Elähināma is a richly-layered masnavi. It consciously mobilizes the formal characteristics of practical ethics and mirrors-for-princes towards its own aims; namely, to solicit the broad audiences of the latter to prescribe a Sufi way of life.

I, thus, read the Elähināma as a Sufi practical ethics, one that I argue was understood as such by medieval audiences across a wide social spectrum. The latter is especially salient when we consider the aesthetics of such texts-they combine the attributes of "popular" literature in which audience reception is of singular importance and "open" literature ${ }^{2}$ for which there are no particular authors ascribed to them (Karla, 50). In order to demonstrate that the Elähinamma may be thus understood, I turn first to a brief discussion of reception theory and genre. It is at the cross-sections of both theories that the multifaceted relationship between the Elähinamma and practical ethics and mirrors may be illuminated. I then analyze the first major signposts that mark for its audiences a shift from a typical reading. I am also interested in the brief moments when we can discern details about the literary and social scene of medieval Nishapur, as well as the poet's socio-religious concerns. One of the most striking narratives in this regard is the "Tale of the Virtuous Woman" (henceforth, TVw), which I examine below and whose structure and motifs resemble that of narratives of popular female saints in Byzantine Christian hagiographies. In addition to the fact that the story touches upon a number of the issues raised within the paper, it may offer rare insight into the circulation and adaptation of Byzantine Christian narratives in eastern Iran.

1 For an analysis of these passages, see Shafi i-Kadkani, 29-35.

2 For more on "open" texts, see Konstan. 


\section{Reception and Genre}

It hardly needs mentioning here that Farid al-Din 'Attār is widely acknowledged as one of the great masters of classical Persian poetry and credited as one of Rumi's two sources of inspiration. The Elähināma thus offers the possibility for elaborating on larger patterns and trends related to medieval PersoIslamic literature. It is also an important source of information on Sufism and the author's attitudes toward religion and society in medieval Nishapur and, in a "circuitous bonding" (Cohn, 17), it offers the opportunity to discern the socioreligious and cultural contexts and the intended and probable audiences that form the backdrop to the Elähināma.

Here, then, I turn to a brief overview of the two methods of analysis pertinent to our discussion, reception theory and genre. ${ }^{3}$ With its sub-branch, reception history, reception theory is the study of innovative iterations of texts. It is specifically interested in how texts interact with, make meaning of, and contend with audience expectations in terms of other texts (Jauss; Martindale 2006; idem 2010). Reception theory allows us to move beyond intractable notions regarding direct transmission and appropriation that often muddy the field of medieval Islamicate literary studies. Many texts that display intertextuality have been typically understood in terms of paying lip-service to or displaying (genuine) humility toward authoritative predecessors and treated as inferior versions. In-depth analyses of what texts take, leave out, and how they present their appropriated materials (organization of materials, discernible shifts in focus), however, can offer a window onto the concerns of later generations and the development of genres. Furthermore, reception history has played a significant role in galvanizing interest in the ordinary reader. Though studies in oral literature and its audiences in medieval Iran are slowly gaining traction, due in large part to the efforts of Julia Rubanovich, ${ }^{4}$ the ordinary reader is by far the most under-appreciated audience in the analyses of medieval Islamicate literature as the quite limited interest in readers has been mostly devoted to courtly patrons.

Throughout this paper, I will analyze how the Elähināma makes meaning of practical ethics and mirrors, both when it adopts and disrupts the latter, and thus how it plays with audience expectations. In tandem, I will focus on the ordinary audience through meaning, which is understood in the latter sense (in relation to practical ethics), and in the tenets of Sufism underlying

3 Despite Meisami's timely call for these types of analyses of medieval Persian texts, little work has been done to date. See Meisami, 236 .

4 See, for example, Rubanovich 2011 and 2015. 
the narratives. It should be clarified here that for our purposes "audience" is the preferred term, and I will use it instead of "reader," since both readers and listeners are co-participants in the reception and circulation of texts in medieval Islamic societies. Moreover, since the courts have received the lion's share of attention, I will focus on the "ordinary" audience..$^{5}$ By "ordinary" audience, I mean those who existed outside the immediate orbit of courts, occupied various social strata, and even if they were non-specialists or not especially active in ta'adob (learning about and cultivating ethics and virtue), they nevertheless enjoyed these texts on multiple levels and were actively involved in their circulation.

One limitation is that, all too often, reception theory in practice presupposes a vertical axis - innovative iterations of classics. The horizontal, detailed studies of what contemporary texts do within and without specific genres and in relation to preceding works, is often missing. As such, it could be quite useful for the ways in which the qesas al-anbiy $\bar{a}^{2}$ (lives of prophets) were resized and reformulated in Sufi hagiographies or how certain tales were retold across various types of texts. Thinking about genre in terms of reception theory as laid out by Hans Robert Jauss (3-45) may therefore be helpful for our purposes.

Genre too is an interesting, yet, relatively little studied aspect of medieval Perso-Islamic texts, especially religious works. This may stem from the fact that, broadly speaking, genre studies is a veritable mine-field. ${ }^{6}$ Nevertheless, the term may have its uses when speaking about medieval Perso-Islamic texts since certain formal characteristics lend themselves to categorization. More importantly, we can and should take our cue from our medieval littérateurs, who characterized their works by generic consideration or devoted time to exploring the rules governing generic types, while being cognizant of the fuzzy lines between and within genres, all of which offer us a fascinating glimpse into the plasticity of Islamicate literature and society. ${ }^{7}$

\section{Between Genre and Reception Theory: Form, Content, Meaning, and Audience}

Several types of practical ethics and mirrors were in circulation in the early Islamic world: from testaments and collections of aphorisms and witticisms

5 This is certainly a broad term since neither the quantity of this audience or named (groups of) readers apart from copyists/editors of manuscripts may be discerned.

6 For an excellent summary of genre studies, see Whetter 2008.

7 For more on the genre and Sufi texts, see Shafi'i-Kadkani 1998. 
to advice literature organized by themes. In some cases, these texts were composed by rulers, who offered their varied experiences to their successors, and in others by littérateurs working in and out of courts, who gathered their own experiences and the wealth of knowledge on good governance and statecraft transmitted down through the ages. In any and all cases, the texts are driven by an interest in the meaning of civic culture, the characteristics of a just society, and maintaining political order. These texts have, as it were, a social function and, as such, are prescriptive and utilitarian. The secondary aim of certain types of practical ethics and mirrors is reception: to make the philosophical underpinnings of a moral and just society accessible to a general, non-specialist audience. These types of texts accomplish this to varying degrees by using open, exoteric, and entertaining anecdotes and tales of popular historical figures and stock characters, who often occupy the same narrative space. Entertaining generations of Muslim audiences, these figures are usually presented as binary opposites; the exemplary model against whom stands the unideal. Such texts are also uncomplicated by esoteric terminology and ornate language for maximum effect and comprehensibility. Elegant, yet simple style and language, in addition to explicit interjections by the author, make the deeper meanings behind the words and deeds of the featured characters, who represent a broad cross-section of society, more accessible. The success and popularity of these works rest, therefore, precisely on the seamless integration of these hallmark characteristics. Put in another way, they rest on the relationship between form (structure and language/style), content (entertaining tales), and meaning (lessons that advance civic culture and political order).

\section{Structure and Content}

One type of practical ethics and mirrors that makes the most of open and popular literature is the frame story/embedded narratives structure. This structure has its origins in the ancient Indo-Iranian literary tradition. Two such texts are Alf leylä va leylä (Thousand and One Nights) and Kalila va Demna, which are translations into Arabic of Middle Persian texts and which garnered broad fame. The latter entered into Sasanian Iran through the efforts of Khosrow I (501-579)'s prolific physician Borzoy who traveled to India and brought important texts back with him, including the Kalila and Demna tales, and translated them into Middle Persian. ${ }^{8}$ It and its Arabic translation by the prolific Umayyad and Abbasid secretary, vizier, and littérateur, Ebn al-Moqaffac (724-759), are important works of practical ethics, but unfortunately they are

8 For more on the literary history of the Kalila and Demna tales from India to Iran to Europe, see de Blois. 
now lost. Ebn al-Moqaffa's version was translated into Persian and adapted as a masnavi by the Samanid court poet and famed "father of New Persian poetry," Rudaki (858-941), who, interestingly, makes a few cameo appearances in the Elähinäma. Generally speaking, the masnavi form has come to be largely associated with medieval Persian romances. However, Rudaki, who composed a number of romances in the masnavi form and set the standard, also illustrated the masnavi's versatility with his version of the Kalila and Demna tales. The Ghaznavid court poet Sanāi (d. 1131), the other of Rumi's two credited sources of inspiration, in a move that would make an extraordinary impact on the development of Sufi literature, composed his religio-didactic work, Hadiqat al-Haqiqa (Garden of Truth), as a masnavi. In addition to being linked by form, the Elāhināma and 'Attār's other masnavis are thus a distinctive combination of the Hadiqat al-Haqiqa through meaning ${ }^{9}$ and Kalila va Demna through content and style.

\section{Language and Ordinary Audience}

The language and style of the Elähināma demonstrate one way in which the text adopts and mobilizes practical ethics and mirrors and indicate that a broad non-specialist, ordinary, audience is intended. Indeed, much like practical ethics and mirrors, the Elāhināma is unencumbered by esoteric terminology or lengthy theoretical discourses. It uses the simple, yet masterful, style with an elegance that belies its simplicity_-similar to what Paul Losensky describes as "artfully artless" for the Tazkerat (xxii) — to construct entertaining, easily accessible, and pithy tales brimming with witticisms, all of which make the narratives easily relatable, recitable, and memorizable.

In its accessibility at the level of language, the Elähināma not only belongs to the period of Persian classical literature that is marked by simplicity of style, but it also repudiates the esoteric elaborations of many contemporary Sufi treatises in its effort to reach an ordinary audience. 'Attār's introductory comments to the Tazkerat are applicable to and relevant for the Elähināma:

my heart would not allow me to speak or listen to anything but these words [of God's friends], except reluctantly and by necessity of compulsion. As a result, I took on the responsibility of relating God's friends to the people of the age, so that I might perhaps drink a cup with them from this table. So it is that Sheikh Abu 'Ali Seyāh (God's mercy be upon him) says, "I have two desires. One is to hear one of God's words. The other is to meet one of his people." He added, "I am an illiterate man. I can't write

9 For a brief comparative analysis between Sanā’i and 'Attār, see de Brujn. 
or read anything. I need someone to speak his words, and I will listen. Or I will speak, and he will listen."

'AṬṬĀR 2009, 44

'Attār makes it clear in this passage that the words of God's friends, even as they are being written down for posterity, should be accessible to the illiterate and, as he makes clear in an earlier passage, to Persian speakers too, as many of these tales were originally told in Arabic (many of the early Islamic historical figures featured were also speakers of Arabic). The last line of Sheykh Abu 'Ali Seyāh's request, "I need someone to speak his words, and I will listen. Or I will speak, and he will listen," also imparts the value of the shared, communal experience of reciting and listening to the words of God's friends. 'Attār no doubt included this particular anecdote in his introduction to signal his intent to offer the words of God's friends in the same vein-communal, shared, written, and oral. And ease of language is one of the ways in which to reach the literate and illiterate alike.

One important aspect related to the ordinary audience, which leads us to our next section, meaning and audience, is the symbols that the sons choose to represent their desires. Each wants access to legendary world-altering sciences such as thaumaturge (second son) and alchemy (sixth son), or objects such as Jamshid's world-seeing chalice (third son), Alexander's water of life (fourth son), and Solomon's ring (fifth son). We should not be distracted by the fact that the sons are kings. Not only were medieval Muslim audiences quite familiar with these popular sciences and tokens, as well as their underlying aims, but the desire to change or escape one's circumstances are fairly common and likely resonated across the board. And the caliph's point is, of course, broadly applicable as well—such trinkets are illusory and the only way to change one's situation is through self-awareness and faith.

\section{Meaning and Ordinary Audience}

In the next few sections, I address the complex relationship between practical ethics and mirrors on the one hand and the Elähinamma on the other through the lens of reception theory. Specifically, I analyze the multiple layers of meaning inscribed in the Elāhināma, which at times disrupts and at others adopts the generic formalities of practical ethics and mirrors, and examine in what contexts these layers of meaning may have been understood by an ordinary audience.

The relationship between form, content, and meaning makes the practical ethics and mirrors ideally suited to prescribing a Sufi way of life. The sophistication of the Elähinamma is precisely manifest in the very fact that it mobilizes 
the structure and form of typical practical ethics and mirrors, while disrupting the latter at the layer of meaning. This is most tangible in the relationship between the bāten ("interior") and zāher ("exterior"). In short, Sufis set great store by the bäten where the heart-the organ that is best able to perceive and commune with the divine-resides. The Sufi adept spends much time and energy learning from the master to condition the $z \bar{a} h e r$, the body, sometimes coming close to eviscerating it. The aim is to cultivate and nurture the bäten to bring one as close to spiritual union with the divine in the corporeal world. ${ }^{10}$ At the meta-textual level, the interplay between the bāten and zāher in the Elähinamma is apparent in the way the short stories relate a particular event, while beneath the surface they are infused with allegorical meaning related to Sufism, ${ }^{11}$ thus disrupting the concern with civic culture and political order of typical practical ethics and mirrors. At the textual level, the entire stated goal of the caliph, who in certain respects symbolizes a Sufi master, is to help his sons, who symbolize (wayward) courted initiates, ${ }^{12}$ push past the bounds of their external desires to seek deeper spiritual truths and undertake the difficult task of conditioning their bodies/desires to allow their souls to contemplate the divine. It might be worth mentioning in this regard, especially since we should be mindful of the text's audience, the significance of the poet's epithet, 'attār ("apothecary"); our poet was his city's apothecary who dispensed and

10 For more on medieval practices and beliefs associated with the bāten and $z \bar{a} h e r$, see Bashir, 27-49.

11 As pointed out by Lingwood in the case of the fifteenth-century "mystically-inclined mirrors-for-princes," Salmān o Absāl, the allegorical function of "a literal or outer (zähir) level of meaning, usually in the form of a tale that makes sense in and of itself, could therefore be used to mask a deeper, esoteric ( $b a \overline{a t} i n)$ meaning impenetrable to those capable of recognizing the images and deciphering the esoteric significance of certain words" for prose. (15) He further states that Jāmi's masnavi is "unique in that it describes this experience in poetic form ... Stated differently, Persian poetry served as the ideal medium for Jāmī to create an unusually esoteric composition: a work of political and ethical advice set within an allegorical romance that actually describes the spiritual journey of the soul" (15-16). However, if one takes a step back, Jāmi's work appears slightly less unique in at least one respect. (As an allegory for the members of the Aq Qoyunlu courts, it is quite unique - but that is a rather different argument.) Much of 'Attār's masnavis composed centuries earlier are neither esoteric or impenetrable and were purposefully cogent along lines similar to typical practical ethics and mirrors as popular texts that made use of open narratives. Furthermore, the Manteq al-Tayr, a quest-epic, describes the allegorical spiritual journey of the soul through the physical flight of a group of birds. The Elāhināma is as interested in the conditioning of the $z \bar{a} h e r$ and spiritual journey of the soul as the Manteq al-Tayr and Salmān o Absāl, in similar ways. For more on this, see below.

12 For more on the multifaceted relationship between masters and adepts, especially the charisma of masters, which is a necessary trait for retaining adepts, see Bashir, $78-134$. 
doled out medicine to heal his neighbor's zāher and his tales (much like those of his fictional counterpart, the caliph) are a salve for their bāten.

The Elähinämeh does not fully circumvent political order and civic culture. It does, however, reshuffle the deck, so to speak. It subordinates the prominent position given to political order and instead advocates steadfastness in faith and awareness and love of the divine. It encourages hemmat ("aspiration" or "effort") in kings (the frame story) and in the populace at large (the narratives and poet's interjections) and thus "public responsibility toward divine law" (Ernst, x). Put in another way, metaphorically, the zāher-the exercise of political order-is a stepping stone, a precondition, for and simultaneously a result of cultivating the bäten - creating and maintaining a just society that ascribes to divine law and within which each member of society is equally responsible. While typical mirrors promote such responsibilities across the social spectrum too, the focus is almost always in relation to kings as important intermediaries between society and the divine.

Indeed, rulers comprise a hefty portion of all these works. Accordingly, they are the linchpin of a well-ordered and functioning society and, when just and ruling according to the tenets of the religion, they hold spiritual and moral authority as the shadow of God (zell Allāh) on earth and are deserving of obedience from their subjects. ${ }^{13}$ And this is of course one of the most important aspects illuminated in practical ethics and mirrors. Although such texts may include examples and tales of fallible corrupt kings as unideal models to reject, they primarily highlight the universal and significant role of kings as intermediaries between the divine and the people in creating a stable and just society. ${ }^{14}$ It is, therefore, not incidental that the caliph is an ideal type in the Elähinäma. However, instead of the well-known archetype of the philosopherking who acts as God's shadow on earth, the Elähināma, in its promotion of the essential tenets of Sufism, promotes the Sufi king as exemplary model. ${ }^{15}$

13 Since viziers dealt with the minute particulars of running state and often wrote these types of texts, they often have a chapter devoted to them and even form the secondary focus of mirrors.

14 For an overview of the king as intermediary in a tenth-century mirrors composed in the eastern Islamic world, see Marlow 2016.

15 One of the most popular kings in the Elähinamma is the irascible Soltān Mahmud who is famous for safeguarding normative Islam and for the conversion of large swaths of conquered territories across South Asia. In these stories he has much to learn about steadfastness in faith and love in all its manifestations and in an interesting few has much to learn about social justice from old women. See Discourse 9, tale 1; Discourse 14, tale 22; Discourse 15 , tale 1 (partially). Other kings (fictional and historical) that are featured in terms of social justice and religion are found in Discourse ${ }_{15}$ (this is the chapter on the fifth son who desires Solomon's ring), such as tales $5^{-12}$. Stories that admonish kings about the 
It is also worth remarking here that the Elähināma's frame story too evokes an older paradigm - the Indo-European motif of a king who, having to decide how to split his kingdom among his heirs, gauges their wisdom by asking a series of pointed questions. The most famous example of this in the Persian literary tradition is that of the mytho-historical king, Fereydun, who bequeaths to his youngest and wisest son, Iraj, the best part of the world, Iran. ${ }^{16}$ Most mirrors, too, stress to varying degrees the importance of testing and selecting the potential heirs to the kingdom and sometimes they outright downplay the significance of patrilineal descent or, more boldly, the common practice of the right of the first-born son. They also dedicate a copious number of pages to underscore the importance of the character and even oversight of petty kings and/ or governors, who, as the king's representatives, are responsible for maintaining social and political order outside the immediate reach of the capital and into the frontier lands. Kings, in mirrors, are encouraged thus not just to set an example for their subjects, but also to monitor, mentor, and guide their regents and/or heirs if and when they are found wanting, before removing them from office. Likewise, the Elähinamma begins at such a moment— the caliph tests his sons, who are kings of various domains throughout the caliph's kingdom, and mentors and guides them when he finds them lacking in spirituality.

Another important aspect of practical ethics and mirrors that the Elāhināma adopts and disrupts can be found in the atemporality it evokes. ${ }^{17}$ Typical practical ethics are road maps to help each individual member of society avoid the pitfalls of their past counterparts, while replicating their successes when possible. They thus convey an atemporal, or — put differently—universal, ideal of society in which each member has his/her specific role to play in order for it to be maintained properly. ${ }^{18}$ They do so through (1) the atemporal space they

accumulation of wealth and power are found in Discourse 16, tales 1-6; Discourse 17, tales 4-6; Discourse 18, tales 1-3; Discourse 19, tale 3. Discourse 21, tale 1, is the best example of the extent to which the world is aright when the king is just.

16 The Elähināma also features the tales of other kings and heroes from the Iranian historical and epic tradition as exemplary models, much like many medieval practical ethics and mirrors. It is, thus, worth noting briefly here that, by and large, the premise that kings in Perso-Islamic texts are intermediaries between God and the people relies on the near-seamless fusion of the pre-Islamic Iranian concept of good rulership with that of the early Arabo-Islamic ideals of kingship. For a more detailed description of the rise of this concept in ninth-eleventh century histories and epic, see Dabiri.

17 For a synopsis of time in Persianate Sufism, see Chittick 2000.

18 It should be pointed out here that, in their cursory assessment, practical ethics and mirrors were cast aside by historians and not considered worthy of in-depth study since this atemporality, it was generally thought, obscured the history of the courts and societies that produced them. Recently scholars have demonstrated that mirrors especially can 
create within the bounds of the text in which ancient and contemporary figures easily occupy; (2) the timeless ideals of society and kingship for which they advocate; and (3) by promoting a normative version of Islam whereby ideological differences are obscured when not repudiated. The atemporality that is expressed in the Elähinamma is constructed similarly yet espouses a different kind of universalism than typical practical ethics and mirrors. It instead promotes a universal faith rooted in love of the divine; a space that erodes ethnic, gender, religious, sectarian, class, and linguistic differences. The diverse individuals from the past and present impart universal truths regarding humanity's relationship both to the divine (or more aptly, living in a temporal world according to the principles of Sufism) and towards each other. In the Elähināma, each member of society is responsible for building a moral and just society according to the tenets of Sufism, whereas in practical ethics and mirrors, the focus is on everyone's relationships to the king to maintain social stability.

We may remark here that the atemporal space that the Elähināma creates is similar to the metaphysical space in Sufism where reason, intellect, love, and intuition reside and may be perceived by the hearts of those who have been trained to annihilate their self (nafs) on the path to residing with the divine (baqā be-'llāh). In certain ways, it is also akin to the concept of na koja a a ba a d ("nowhere land") developed and expounded upon by 'Attār's near contemporary Shehāb al-Din Sohravardi (1154-1191) in whose philosophical works mysticism permeates. More so, however, the Elähināma as a whole evokes, to use William Chittick's phrase, "one version of the question of tawhid ["oneness of God"]: how the many are related to the One" (589). As has been frequently noted, the narratives in the Elähināma are quite often thematically different than the one to which they are assigned (by the son's aims/desires). It is this assortment of characters and their cross-thematic narratives - their variegated struggle on the path toward spiritual union with the divine - that are bound within a single narrative (the frame story) that conjures up this version of the question of towhid.

The question of towhid in the Elähināma is, nevertheless, a complex one. Comparatively, in the Manteq al-tayr, the concept of towhid and vahdat-e vojud ("unity of being") is manifested more concretely. In the latter, a flock of different

and often do corroborate historical events found in chronicles, court and local histories and help the diligent historian paint more refined portraits. For more, see Lambton, Bosworth, Yavari, Lingwood, and Marlow. Of equal significance, the finer details about certain personalities, life in general at court, and of various relationships among courtiers (including that between patron and composer) emerge when read in conjunction with these other types of histories. 
species of birds' arduous and, for some, fatal quest to search for their hidden king (an allegory for the spiritual journey of the soul) ends in a visible manifestation of how the many are related to the One; only thirty birds of hundreds reach the threshold of the king's court when they are confronted with a mirror in which they, hovering in the air altogether, are the king, Simorgh (lit. "thirty birds," but also the name of the mythical bird of Iranian lore). Conversely, in the Elähinäma, as just noted, the audience is encouraged to perceive towhid through the varied lessons on universal faith and love of the divine embedded within the tales of individuals from different eras, regions, and confessions.

Shafi'i-Kadkani, citing previous scholarship, highlights (37) the fact that the term vahdat-e vojud does not appear in the Elähinamma. Yet, he observes, whoever put together the Elähinäma's introduction(s) on towhid adopts the language of 'Attār's contemporary, Ebn 'Arabi (1165-1240) who is largely credited with coining the term. ${ }^{19}$ Shafi i-Kadkani also notes that the original title of our masnavi was Khosrownāma (King's Book) (ibid., 47-63). The original title demonstrates that the structure, style, content, and format were indeed intended to evoke that of typical mirrors, which sometimes were also titled generically, as in, for example, the eleventh-century Ādäb al-moluk (Customs of Kings) by the Nishapurian Saālebi (961-1038). Though khosrow is a generic term for Persian kings, it arose from the enduring popularity and the epitome of a just monarch in the medieval Islamic world, the sixth-century Sasanian king, Khosrow I. The original title of the Elähinamma thus also evokes the latter, while following in the tradition of previous mirrors such as the Qäbusnāma, which was composed in the early eleventh century by the Ziyārid ruler of Tabaristan, Key Kāvus, for his son. Were the new title and introduction added by later editors/ copyists as part of a concerted effort to ensure audiences grasped all the layers of the text? Or were these actions a symptom of the editor's zeal for not only the idea of towhid but also for the delicate ways the Elähināma evokes it? The more pertinent question here is: to what extent might 'Attär's audience, aside from later medieval copyists and editors, have perceived the concept of towhid or any of the Sufi doctrines and codes of conduct at work beneath the surface of the tales?

Whetter makes an insightful observation that may be applicable here with some adjustment; he notes (3) that parody is useful to understanding not only specific features of a genre, but also of the audience's awareness of those features. The Elähinamma is certainly not a parody; however, if we consider the vast popularity of practical ethics and mirrors, it is reasonable to suggest that an

19 However, as Chittick notes (1960-2007), the term vahdat-e vojüd does not appear anywhere in Ebn 'Arabī's corpus as we have it. 
audience familiar with them would have been equally cognizant of the marked difference at the level of meaning between the latter (promoting civic culture and political order) and the Elähināma (promoting civic culture and political order through universal faith and prescribing a Sufi way of life). Although we may not be able to gauge the extents to which audiences may have grasped the finer details of the esoteric world of Sufism that the lessons evoke, we may make the cautious observation that Sufi khānaqūhs (orders) had, by the twelfth century, become an equalizing force across the socio-political spectrum. ${ }^{20}$

In general, in the medieval period, khānaqua hs exerted considerable social influence. They were ubiquitously present and popularly visited sites across medieval cities and towns. They were educational centers and places where pilgrims and travelers could temporarily reside and locals were able to partake in certain rituals. Members of Sufi orders, too, actively went out on missionary assignments, supported reform, and promoted spiritual revivals. By the beginning of the eleventh century, Nishapur boasted many prominent figures who were largely responsible for ushering Sufism into the mainstream of Islamic social life and institutions, as Malamud notes (427). Some of the most important khānaqāhs in Khorasan were established in Nishapur-first, as small houses by charismatic Sufi masters such as Hasan b. Ya'qub, Abu al-Hasan, and 'Ali b. Ahmad Foshanji, and, later, as independent institutions with rules and codes of model behavior between masters and disciples as developed by the Nishapurian Abu Sa'id b. Abi al-Kheyr. By the twelfth and thirteenth centuries, Sufism was an integral part of the social fabric of Nishapur, despite its later start compared to the rest of Greater Khorasan. ${ }^{21}$ We thus may understand the Elähināma as a text that complimented simultaneously the "broadly based social movement" Sufism had become (Ernst, ix) and the hagiographies of the masters which provided contemporary models of exemplary behavior. In this light, we may conclude that the basics of the coded terminology of the Sufis and the caliph's insistence on cultivating the soul would have been more than amply understood.

\section{The Signposts: Between Genre and Audience Expectation}

Heretofore, we have considered meaning on two levels-in terms of Sufism and in terms of how the Elähināma makes and disrupts meaning out of the

20 For more, see Hodgson, Rajā̄ì, Danner, and Lewisohn.

21 For the importance of Khorasan and Nishapur in the establishment of khānaqāhs, see Böwering and Melvin-Koushki and Malamud. 
familiar practical ethics and mirrors for an ordinary audience. At this juncture, we turn to another fruitful intersection between reception theory and genre: namely, how the Elähināma contends with audience expectation. In the next few sections, I highlight the initial signposts that illustrate how the Elähināma signals for its audience a different reading than that of typical practical ethics and mirrors. I then turn to the "Tale of the Virtuous Woman" as a prime example of how the Elāhināma addresses two quite general audiences, Christians and Muslims.

\section{The Source of the Story: The Old Man 22}

Until now, I have focused on the main frame narrative of the Elāhināma, that of the caliph and his sons. However, that tale is itself framed by two beyts (distichs) of the "yeki bud, yeki nabud (once upon a time)" type: there once was a distressed old man with a story to tell. All we know of the old man is that he traveled the world (jahān gardida), lost his beloved/friend (gom karda $y \bar{a} r$ ), was bewildered (sarāsima del) and distressed (āshofta). To a modern reader, this may signal an unreliable storyteller. However, if we draw on the cultural, religious, and literary knowledge of the time, the image and story that immediately come to mind is that of Yusef (Joseph), whose epithet is the lost-wanderer (gom gashta) and whose unrequited love story with Zulaykhā would later become one of three popular metonyms for the nigh impossibility of union with the divine in the temporal, corporeal world, and one that 'Attār retells in the Elāhināma. An audience familiar with the basics of Sufism's

22 The beyt is as follows:جهان كَديده ایى ك كرده يارى / سراسيمه دلى آشفته كلى . This line along with the approximately fifty preceding lines belong to MSs. A F I B G H L D U and Q, but not S, which Shafi'i-Kadkani has chosen as the basis of his edition ('Ațtāar 2013, 452). Mss. H B F D Q and S are among the oldest ones available (ibid., 63), while Ms. A, which is the basis of Ritter's edition, and MS. F are accordingly copies of the oldest versions of the work (ibid., 73-77). Ritter also suggests based on internal evidence that while the version, of which A is a copy, might not have been 'Attār's own original (which has yet to be found), but may be that of an immediately-successive editor (ibid., 74; Ritter $1989,11-13)$. Therefore, I include the beyt in my analysis in the strong likelihood of its authenticity. Even if these lines derive from editions compiled by near-immediate editors, it does not change the function of the beyt, which I argue, is a recognizable signal to the audience that the text is a departure from typical practical ethics and mirrors. If this line were indeed added later, the editor(s) would have been drawing from the Elähināma itself. One illuminating example is that of a distressed man at an extravagant party thrown by a baker in honor of Shebli. The distressed man randomly tells Shebli that he does not know the difference between good and evil. This is a moment that leads to the moral of the tale-Shebli tells him to look no further than the host who threw the party because of his fame rather than give him a loaf of bread out of mercy when the latter thought he was an anonymous beggar ('Ațtāin 2013, 178). 
coded terminology would have recognized that being bewildered and lost is the ideal state to be in for seeking union with the divine, a condition widely lauded by Sufi poets and wayfarers. The Elāhināma also features a number of stories where distressed old men serve as a catalyst for the learning of a moral lesson. ${ }^{23}$ These descriptors, then, signal that we have an authoritative narrator who is immersed in the Sufi path. ${ }^{24}$

\section{The Caliph}

Our next signal is the caliph, who is the main narrator. As pointed out by Ritter (1989) and Foruzānfar (2010), the caliph reveals the common and mundane impulses driving each of his sons' grandiose aims as an inability to tame their baser instincts. The caliph counsels his sons and tells hundreds of tales of varying lengths to illustrate the virtues of hemmat (effort), self-knowledge, and awareness of the divine in formulating one's goals in life. From the first son's stated ambition, 'Attār signals to his audience a shift in focus from temporal power to that of the divine. For instance, the first son is warned that chasing lust depletes his soul's reserves and the fifth son is cautioned that chasing ultimate power comes with a terrible price; namely his soul. The immediate concern is the soul, which accordingly seeks to return to its original source, the divine. And, as noted above, cultivation of the soul goes hand-in-hand with controlling one's baser instincts - the control of the zāher to nourish the batten. Since we addressed the caliph at length above, we now turn to the most important of these first signals, love.

\section{The First Son's Ambitions and the Caliph's First Story: The Tale of the Virtuous Woman}

After the caliph asks his sons about their ambitions, the first son excitedly proclaims that his ultimate aspiration (morād) is to be with a fairy princess who is renowned for her great beauty and gentle soul. He further informs his father that unless he can be with her, he would have no other religion except for madness (divānegi), which is itself an important signal. For much like the world-weary, distressed old man, divannegi is one of the most common Sufi tropes for the lover whose mental faculties are consumed with desire for the beloved (the divine).

23 See $n .22$ above, specifically on Shebli.

24 It may be worth noting here that the Masnavi-ye Mánavi opens up to a distressed forlorn reed who sings about separation and invites his audience to listen to his tales. Both stories begin with kings who are so in love with an unattainable beloved that they are near inconsolable in their miserable state. The first stories are both on love, beauty, loss, and separation in context of the divine. 
The father understands that at the heart of his son's ambition is its binary opposite, lust, and admonishes him and cautions him that

any man who is entrapped by his lust /

depletes the stores of his soul ${ }^{25}$

'ATTĀR 2013, 131

But he does not altogether crush his son's aspirations. He tells him instead that the ideal woman is one who, if she is like a man in conduct, is a complete stranger to lust (ibid.). Then he dives into his first tale which details the misadventures and hardships of an exquisitely beautiful and virtuous woman, who, in a twist, becomes "a leader among men at God's court" (ibid.). ${ }^{26} \mathrm{~A}$ woman to whom no man comes close in terms of virtuousness and piety, despite the pronouncement that the ideal woman is like a man in conduct (in fact, she puts to shame nearly every man she encounters).

Herein follows a brief synopsis of the tale: A woman is separated from her husband because he has gone on pilgrimage to Mecca. She attracts the unwanted advances first of her brother-in-law and survives a trial by stoning after, in revenge for her rejection, he accuses her of infidelity. In her travels, she encounters a number of other men who lose their reason at the sight of her beauty and who try to take her by force. The last group of men she encounters are seafarers who each fall madly in love with her and do their best to conceal their violent intent. She prays to God to rid these men of their lust or to grant her death, for death she claims, is better than such a life. She immediately falls unconscious. A fire-storm rises and causes the death of the sailors, while leaving her alive onboard the ship with its wealth of goods. Eventually, the ship safely reaches shore, where she awakens and then puts on men's clothes to disguise her beauty. When she is found by some men who ask her who she is, she says that she will not say another word unless they bring her to their king. The men run off and tell their king that there is a handsome young man sitting on a ship full of goods who will only speak to him. When the king arrives, the woman, still disguised as a man, tells him of her tale and then offers him all the goods on the ship for one thing in exchange - to have a shrine built on the coast where she landed and to be left to pray to God night and day. Awed by her, the king agrees. Years pass, when the king is on his death bed, he calls his army and counselors and tells them that he has chosen the hermit (the

25 Translations of the Elāhināma are mine.

26 This beyt does not appear in Ms. S, but does appear in Mss. A F I B G H U Q D ('Ațtāar 2013, 452). 
virtuous woman) to lead them after his death. They agree and they come to her with the king's request. She tells them all that, in order to lead, she will need to marry a woman and that they should bring her all the eligible women and their mothers. When the women and their mothers arrive, she reveals herself to be a woman and tells them to inform their men. Incredulous, the women tell their husbands and fathers, who in awe, decide to tell her that she should, as heir apparent, rule as a man (presumably, since she was living as one) or choose someone fitting from among them to be the king. She chooses one of the worthiest among them and returns to her prayers and performing miracles by healing the sick and disabled.

At this juncture, the caliph interrupts the story to admonish his son and says:

not for a kingdom did she budge from her spot /

but you, son, would turn the whole world upside down for bread crumbs (ibid., 140)

The caliph then resumes the tale, relating that all the men who had survived their encounters with her, but had been maimed or disabled (in ways correlating to the harm they caused her), set out on a journey to visit the holy woman hermit who, they have heard, has the ability to heal. Each of the men happen to encounter each other, including even the virtuous woman's long-lost husband who accompanies his brother (whose sins against his wife he later forgives after witnessing the sincerity of his shame and sorrow), and they all decide to travel together. When they arrive at the hermit's shrine, the woman is overjoyed to recognize her husband. But seeing the men who had tormented her with him, she veils herself and keeps her identity hidden. When they come forward, they ask her to heal them, and she states that if they each confess their sins, they will be healed. They accept her terms and confess their sins. Acknowledging their sincerity, she prays for them and they are healed. Afterwards, her husband tells her that she reminds him of his wife and she reveals herself to her husband and tells him that she always had remained faithful to him and then she begins to recount all her travails. The two rejoice in their reunion, while the other men rejoice and are ashamed of the role they played in her trials. She makes her husband king and appoints the Bedouin, the one man who in all her trials had aided her, as his vizier and returns to worshipping God in her shrine.

This tale touches on a number of issues we have raised throughout the paper, much of which are directly related to the way in which the Elähināma destabilizes typical practical ethics and mirrors even as it adopts their generic stance. First, we may note further that the universalism which 'Attār espouses 
erodes differences not only in class and confession but also in gender and those who circumvent gender normative performances (the virtuous woman is a cross-dresser and miracle healer). And it is important to note here that across different types of Sufi texts women do not appear nearly as often as masters or models of sainthood. When they do, much like the men, their holiness comes from overcoming their impulses and carnal desires as well as being charismatic figures. Even still, most medieval female Sufis derived their status through the self-control they exhibit in combination with familial bonds; they were often the wives, widows, mothers, and daughters of saints or masters. ${ }^{27} \mathrm{In}$ the Elähinamma by contrast, no one group may ever claim moral superiority at all times and in every circumstance, except women and the prophets Moses, Jesus, and Mohammad. Not even Sufi saints who often have important lessons to learn from the laity.

Second, and relatedly, is the various notions of kingship that are mobilized even as they are disrupted. As noted above, however much Islamic political theory acknowledges the role of the populace in social stability, this is usually framed around the king-either in terms of obedience to the king when he rules justly or the reason for kings to rule justly so as not to incite rebellions against the state. The tale, conversely, places much greater weight on the populace in selecting their king and the principle of selecting the wisest and most religious as heir-apparent rather than through right of the first-born son. Though the virtuous woman turns down the king's offer, it is the community which insists that she, despite her great reveal as a woman, rule as a man or be king-maker. The significance here is that the community recognizes her religious authority, regardless of her gender. Together, the stories of the caliph and the virtuous woman offer us a glimpse into what a Sufi philosopher king's reign might entail.

The way in which female sanctity and sainthood are portrayed in TVw indeed offers an interesting commentary on kingship. Across a wide variety of medieval texts including the Elähināma, the king is an important intermediary between the divine and society, as mentioned above. In TVw, the relationship between kingship and religion is depicted, quite uniquely, in the form of a celibate marriage. Though the text does not mention if the virtuous woman and her husband resume marital relations, we can presume that they did not. The now holy virtuous woman has by default not only selected her husband as king, but has made him a virtuous (celibate) king. The king-maker has installed her male equivalent on the throne. Yet, religious authority nevertheless 
remains under her domain and she provides him with both temporal (kingly) and religious authority.

The control she exerts over her virtue extends, thus, to her husband, and perhaps by extrapolation society as their moral leader and model. It also extends to the men who threatened her with sexual violence. Some perished at sea; however, the ones who survived their encounters with her, were maimed or injured as part of their just desserts. However, their survival enabled the possibility that they could learn eventually to control their impulses, in which case they were eventually lead back to the virtuous woman and healed. Two important notes are worth mentioning here, both of which may be formulated within the context of the interplay between the interior and exterior: we may glean from this that not only is there real risk to the bäten when one does not exercise control over the $z \bar{a} h e r$, but that it can cause the latter serious harm as well. For the $z \bar{a} h e r$ to be fully functional, in other words, the bāten must be nurtured.

As remarked upon above, zāher/bāten operates on many levels throughout the Elähinamma and in Sufi thought. Here, we explore it as a motif, specifically one that drives the plot, together with another important and related dual concept; namely, love and beauty. In Sufism, love and beauty are the ultimate movers of Sufis who often describe God as beauty itself. Much time and energy has been devoted by Sufis over the centuries to appreciating beauty in all its manifestations - as emanations of the divine - and to describing the divine as a beautiful cruel beloved because of the difficulty (near impossibility) of union with the divine, or the death before death, fanā be-'llāh ("self-obliteration in God"). Thus, as much time has been expended on beauty, simultaneously, Sufis often speak longingly of that all-consuming unrequited love and describe the beloved as cruel and themselves as madmen irreversibly lost.

The virtuous woman's bäten (her beauty) and $z \bar{a} h e r$ (control of her virtue) are the motifs that set the plot in motion, and this operates differently for the men than for the virtuous woman herself. While, for her, they are the catalyst for movement, for the men, beauty is a metaphor for the unobtainable beautiful beloved. The men resemble, on the surface at least, Sufis on the path to attain spiritual union with the divine. However, they are not true Sufi adepts; they confuse, like the caliph's first son, the zāher for the bāten-lust for love, and much more so, divine love. Thus, it is also their inability to control their $z \bar{a}$ her that sets them, too, on a path to misfortune. For the woman, her beauty not only sets her, at first and seemingly, on the path to misfortune, it later grants her religious authority and brings her as close to the divine as humanly possible. Her beauty is thus one of the many manifestations of the divine. And we should consider this in conjunction with the moment the woman begs God for 
death to preserve her virtue and faith while she is out on the open sea with no other recourse. ${ }^{28}$ What she receives in answer to her prayer is the death before death that Sufi adepts and masters long for and the experiences of which have been expounded upon in esoteric autobiographies and biographies of Sufi masters. The story of TVw in this way adopts this other generic type. For indeed, when she awakens from having fainted, she is able to perform healing miracles, much like the claims made of medieval Sufi saints in the biographies written by their disciples. We assume then that indeed her soul did achieve the near unachievable - union-even if she was not conscious for it. The men who were harmed by their inability to control their $z \bar{a} h e r$ - their baser instinctswere able to receive her love and healing powers, like any sincere Sufi adept aching for the love of their masters and the divine, only after they learned to control their $z \bar{a} h e r$. The virtuous woman is also thus a Sufi master. ${ }^{29}$

While there are motifs from other popular narratives, like the qesas alanbiy $\vec{a}$, that are echoed in the $\mathrm{TVw},{ }^{30}$ an interesting aspect here is that the lives of Muslim and Suf female saints and masters, within and without the context of the Elähinäma, are not constructed in this particular way. Beauty is rarely a motif that drives the plot of Muslim or Sufi saints into a tale of harrowing escape after escape from the unwanted attentions of men. Dick Davis has noted the strong resemblance in the core plot of TVw with Ancient Greek Novels - from the separation of lovers to their travails (including the popular

28 Interestingly, the soul and love are likened to the sea. See Discourse 14, story 24, for the significance of the sea of the soul and love.

29 There are a few overt similarities between this tale and those that describe the miracles Sufi masters performed and the intimate relationship between them and their adepts. For more on what narratives of historical saints achieve, see Bashir, 50-104.

30 For instance, when the virtuous woman veils herself from her husband, his brother, and his companions so that she is not recognizable, there is a parallel to the tale of Joseph. Indeed, this is a popular motif in Sufi literature that also expends time and energy on the veil as a symbolic divide between this and the next world. The tale of Joseph who hides himself from his brother Benjamin also appears in the Elāhināma in Discourse 3, story 6. Interestingly, he is a beloved who is pursued relentlessly by Potiphar's wife. However, there is a fundamental difference, since Joseph requires divine assistance to resist her advances and eventually marries her once an appropriate amount of time has passed. In Sufi literature, Potiphar's wife is a Sufi-style lover and treated sympathetically in her madness for her beloved. See Discourse 8 story 7 and Discourse 20, story 7. The threat of violence on a ship and a storm that guides the ship safely to shore through prayers to God is reminiscent of Jonah's story-although the circumstances of that violence and the aims of Jonah and the virtuous woman differ significantly: the former flees God, while the latter flees men because of her faith in God. Further still, the former is disappointed by God's mercy toward the repentant sinners, while the latter happily heals the men who have come to atone for their sins (on this last point, I thank D Gershon Lewental for his insight). 
motif of the shipwreck), travels, and eventual reunion), but could not account for how they appeared in a medieval Sufi tale. If we look to examples of Byzantine Christian hagiographies, we see many texts focused on female saints that employ these themes in similar order using the same theme of female beauty. ${ }^{31}$ The most pertinent and famous examples are: (1) Thecla in the Acts of Paul and Thecla and the later Life and Miracles of Thecla; (2) Mittidia in PseudoClementines Recognitions; and (3) Eugenia in the Passion of Eugenia.

Although TVw departs from these tales in certain ways, nevertheless the story's backbone is an amalgamation of the aforementioned. For instance, Thecla's beauty forces her on a journey that is replete with multiple threats of sexual violence and repeated near martyrdoms. In order to remain in the presence of an authoritative male figure/benefactor, Thecla offers to cut her hair presumably to disguise her beauty/herself to remain in the presence of Paul the Apostle (whereas the virtuous woman disguises herself completely in order to gain the protection of the king). Apart from their adventures of harrowing escapes, the virtuous woman and Thecla undergo divine baptism (when she is about to be violated in a most gruesome and sadistic way Thecla takes advantage of an opportunity for baptism as a pool of seals are brought in to the arena. When, in the name of Jesus, she jumps in, lightening strikes and the seals float up, dead; by contrast the virtuous woman, when cornered on the ship by her would-be rapists prays to God for death, who sends a firestorm which burns the men to ash). Finally, they both end up in secluded spots (Life and Miracles of Thecla), where a shrine is built for them and which becomes a place where they perform miracles.

As for Mattidia, the similarities are likewise readily apparent: a beautiful woman is separated from her husband, flees the unwanted advances of her brother-in-law, and after a series of travels and a shipwreck that leads her to a foreign land where she resides for years, she holds onto her virtue until she is eventually reunited with her long-lost husband (in a rather engineered recognition scene by the apostle Peter who then baptizes the whole family). In Eugenia's tale, we find a female saint in disguise living in a monastery, who, like the virtuous woman, becomes a leader among men when she is chosen by her brothers in faith to be the abbot and leader of the monastery. She, too, has a great all-in-one reveal and recognition scene that reunites her with her family,

31 Eastern Christian hagiographies, specifically those composed during the Sasanian period and are famously known altogether as the Persian Martyr Acts, demonstrate a familiarity with the Sasanian epic tradition, which, in addition to their attempts to undermine Zoroastrian doctrine, they employ to subvert the authority of the kings. For more, see Walker. 
the ruling elite of Alexandria. Aside from other such similarities, it is the commentary on spiritual and earthly leadership and its relationship to the body politic that binds Eugenia, Thecla, and the virtuous woman. ${ }^{32}$

Such similarities raise several important questions regarding 'Attār's library and of course his social milieu. Certainly, TVw intimates 'Attār's familiarity with at least an amalgamated version of the Mattidia, Eugenia, and Thecla tales. Might I dare go so far as to suggest that TVw is 'Attār's own reworking of these or similar tales in circulation? In any case, it should not come as a surprise that 'Attār and his Christian and Muslim audience would have been familiar with such tales and motifs. As for the former, in the first place, Christian communities flourished in the late Sasanian Empire ${ }^{33}$ and continued to do so in the Islamicate world and, especially for our purposes, twelfth- and thirteenthcentury Nishapur. Archaeological and textual evidence suggest that inasmuch as Christians, Jews, Buddhists, and Muslims had their places of worship located in separate quarters, medieval Iranian cities were nevertheless teeming melting pots and inter-confessional interactions were frequent. ${ }^{34}$ In terms of the Mattidia narrative, it should be mentioned here that Pseudo-Clementines, "an enigmatic corpus of writings whose affinities with important streams of Palestinian and Syro-Mesopotamian religious communities" (Reeves 2016, 204), displays a quasi religio-political interest in Iranian history and genealogy as it relates to Judeo-Christian history. ${ }^{35}$ Eugenia is also popularly attested, appearing in Latin, Greek, Armenian, and Syriac versions throughout Asia and North Africa. ${ }^{36}$

As for the possible circulation of the Thecla narrative among the Christian communities living within Iran, we should consider several routes. First, the Acts of Paul in which the Acts of Thecla appears is one of the foundational apocryphal texts for the Christian community throughout the late antique and medieval Christian world. Not unrelated is the fact that Thecla is one of the most popular models of female sanctity and chastity (for instance, Eugenia's tale

32 I am currently working on a paper that analyzes the deeper structures of these texts in relation to plot and motif in articulating female sainthood.

33 It is a well-known fact that Christians from the Roman Empire were brought and resettled in Iranian cities after several decisive victories over Rome. It is not inconceivable that they would have brought their stories with them.

34 Although the trope of the disheveled old man is too common to be considered significant on its own, it is worth mentioning that it does appear quite often in the Ancient Greek Novels and Christian hagiographies, too.

35 A number of paragraphs are dedicated to an exposition of the Old Testament genealogical tables which considers the origins of Zoroastrianism through the Biblical figure, Nimrod (Smith, I, ch. 30) and the origins of the "Persians" through Abraham (ibid., ch. 33).

36 The story is situated in Alexandria. 
frequently references it through various direct and indirect modes) and her story is one of the earliest of Christian saints to spread rapidly across east and west. ${ }^{37}$ In late antiquity, the Acts of Thecla was in wide circulation within and without the Iranian political and cultural sphere, such as Asia Minor, where the tale takes place, Sasanian Mesopotamia, Egypt, ${ }^{38}$ Georgia, and Armenia. In addition to the latter two, another route that would transition us into the medieval period is the one that follows the Manichaeans. The Manichaeans flourished in late antiquity and their missionary work took them through the western and north eastern Iranian lands and Byzantium. Although they were persecuted by the early Abbasids, nevertheless, they "persistently survived, clandestinely perpetuating their teachings" (Reeves 2011, 281). In their missionary work, Manichaeans set about translating not only the works of Mani himself but also of the apocryphal acts. Stephen Davis focuses on the Manichaeans' active dissemination of the Acts of St. Thecla in Egypt and makes the astute observation that they "considered her the paradigmatic virgin exemplar for women" (2001, 101). Of great significance also is the relationship between the development of Islamic mysticism and the establishment of khänaqähs to post-Islamic Manichaean developments in Greater Khorasan. ${ }^{39}$ And finally, one pertinent aspect to keep in mind is the role of Ebn al-Moqaffac, our translator of the Kalila and Demna tales, who was the famous and powerful secretary of the Umayyads and early Abbasids, and played a significant in role in shaping early medieval Islamic statecraft and its literature. The loss of his works is felt here all the more heavily. According to the numerous herseographical accounts we have, although Ebn al-Moqaffa converted to Islam, he remained at heart a Manichaean and ran a circle of influential co-religionists many of whom were also part of the bureaucratic elite of the Umayyads. Though much of his surviving works illustrate an affinity with other Sasanian and Zoroastrian texts, ${ }^{40}$ one can only imagine what materials were at the disposal of Ebn al-Moqaffa' and his inner circle and which were transmitted by them. ${ }^{41}$

37 Thecla's textual afterlives will be explored in hagiographies from east to west in a forthcoming volume I am co-editing.

38 Another possible avenue to pursue for the transmission of the Thecla narrative are the Arabic translation(s) of the Acts of Thecla, which are housed in St. Catherine's Monastery in the Sinai. There is one tenth-century manuscript (Ms. 513) and one twelfth-century manuscript (Ms. 534); both currently remain unedited.

39 See n. 21 for more.

40 For an extended discussion of the Sasanian/Zoroastrian tenor of Ebn al-Moqaffa"s works, see Shaked.

41 For more on this, see Arjomand. 


\section{Conclusion}

In this paper, I have attempted to highlight the ways in which the Elähināma takes up the formal characteristics of typical practical ethics to disrupt them at the level of meaning to invite a broad audience to consider and explore and enact what a Sufi moral and just society might be. TVw, as the first tale, is exemplary of all the tales in the Elähinama. It brims with lessons on kingship (the selection of regents and heirs to the throne), civic culture and political order, towhid, love and beauty, self-awareness, steadfastness in faith, and $z \bar{a} h e r$ and bäten. TVw, furthermore, much like any number of stories peppered throughout the Elāhināma is one about exemplary religious virtuousness that invites a broad audience familiar with the basics of Sufi coded terminology to prescribe a Sufi way of life. TVw thus promotes ordinary folks from all walks of life as exemplary models to partake in the hemmat or effort that is necessary to cultivate their spiritual lives. TVW also tells us of the kinds of stories and motifs that may have been popular among Christians and Muslims, which we can presume were told and utilized for maximum effect and the social value they had.

\section{Select Bibliography}

S. A. Arjomand, "Abd Allah Ibn al-Muqaffa' and the 'Abbasid Revolution," Iranian Studies 27.1-4 (1994), pp. 9-36.

Farid al-Din 'Attār, Elāhināma, ed. M.-R. Shafi'i-Kadkani, 3rd ed., Tehran, 2013.

Farid al-Din 'Attār, Ilahi-nama die Gespräche des Königs mit seinen sechs Söhnen: eine mytstiche Dichtung von Farīdaddīn 'Ațtār, ed. H. Ritter, 2nd ed., Tus, 1989.

Farid al-Din 'Attār, Manteq al-tayr, ed. S. S. Gawharin, 1oth ed., Tehran, 1995.

Farid al-Din 'Attār, Manteq al-tayr, tr. D. Davis and A. Darbandi as The Conference of the Birds, London/New York, 2011.

Farid al-Din 'Attār, Tazkerat al-owliya $\bar{a}$ ', ed. by M. Estelami, 2nd ed., Tehran, 1984.

Farid al-Din 'Attār, Tazkkerat al-owliyā', ed. M.-R. Shafi'i-Kadkani, tr. P. Losensky as Farid ad-Din 'Attār's Memorial of God's Friends: Lives and Sayings of Sufis, New York, 2009.

S. Bashir, Sufi Bodies: Religion and Society in Medieval Islam, New York, 2011.

F. de Blois, Burzōy's Voyage to India and the Origin of the Book of Kalìlah wa Dimnah, London, 1990.

E. C. Bosworth, "Mirrors for Princes," in J. Meisami and P. Starkey, eds., Encyclopedia of Arabic Literature, London, 1998, pp. 527-528.

Gerhard Böwering and M. Melvin-Koushki, "Kānaqāh," in EIr., London/New York, 2010; online: http://www.iranicaonline.org/articles/kanaqah (accessed: 29 June 2017). 
J. T. P. de Bruijn, "Comparative Notes on Sanā'ì and 'Aț̣āa," in L. Lewisohn, ed., The Heritage of Sufism, vol. 1, Classical Persian Sufism from its Origins to Rumi (700-1300), Oxford, 1999, pp. 361-380.

W. C. Chittick, "Time, Space, and the Objectivity of Ethical Norms: The Teachings of Ibn al-Arabī," Islamic Studies 39.4 (Winter 2000), pp. 581-96.

W. C. Chittick, "Waḥdat al-shuhūd," in $E I^{2}$, Leiden, 1960-2007; online: http://dx.doi .org/10.1163/1573-3912_islam_SIM_7819 (accessed: 02 May 2017).

D. Cohn, "Fictional versus Historical Lives: Borderlines and Borderline Cases," Journal of Narrative Technique 19.1 (Winter 1989), pp. 3-24.

M. Cooperson, Classical Arabic Biography: The Heirs of the Prophets in the Age of alMa'mūn, Cambridge studies in Islamic civilization, Cambridge/New York, 2000.

G. Dabiri, "The Shahnama: Between the Samanids and Ghaznavids," Iranian Studies 43.1 (February 2010), pp. 13-28.

V. Danner, "The Early Development of Sufism," in S. H. Nasr, ed., Islamic Spirituality: Foundations, vol. 1, New York, 1987, pp. 239-64.

D. Davis, Panthea's Children: Hellenistic Novels and Medieval Persian Romances, New York, 2002.

S. J. Davis, The Cult of Saint Thecla: A Tradition of Women's Piety in Late Antiquity, Oxford, 2001.

C. W. Ernst, Rüzbihān Baqlï: Mysticism and the Rhetoric of Sainthood in Persian Sufism, Routledge Sufi series, London/New York, 1996.

B. Foruzānfar, Sharh-e ahvāl va naqd va tahlil-e āsār-e Sheykh Farid al-Din Attār Nishāburi, 2nd ed., Tehran, 2010.

M. G. S. Hodgson, The Venture of Islam: Conscience and history in a world civilization, vol. 2, The Expansion of Islam in the Middle Periods, Chicago, 1974.

H. R. Jauss, Toward an Aesthetic of Reception, tr. T. Bahti, vol. 2, Minnesota, 1982.

G. A. Karla, "Life of Aesop: Fictional Biography as Popular Literature?," in K. De Temmerman and K. Demeon, eds., Writing Biography in Greece and Rome, Cambridge, 2016, pp. 47-64.

D. Konstan, "The Alexander Romance: The Cunning of the Open Text," Lexis 16 (1998), pp. $123-38$.

A. K. S. Lambton, "The Dilemma of Government in Islamic Persia: The Siyāsat-nāma of Niz̄ām al-Mulk," Iran 22 (1984), pp. 55-66.

A. S. Lewis, "Eugenia," in Select Narratives of Holy Women from the Syro-Antiochene or Sinai Palimpsest as written above the Old Syriac Gospels, ed. and tr. A. S. Lewis, Studia Sinaitica 9-10, London, 1900, pp. 1-35.

F. D. Lewis, "Sexual Occidentation: The Politics of Conversion, Christian-Love and BoyLove in 'Attār," Iranian Studies 42.5 (December 2009), pp. 693-723.

L. Lewisohn, The Legacy of Mediaeval Persian Sufism, London/New York, 1992. 
C. G. Lingwood, Politics, Poetry, and Sufism in Medieval Iran: New Perspectives on Jāmìs Salāmān va Absāl, Studies in Persian cultural history 5, Leiden, 2014.

P. Losensky, "Introduction," in Farid ad-Din 'Attār's Memorial of God's Friends: Lives and Sayings of Sufis, New York, 2009, pp. 1-38.

M. Malamud, "Sufi Organization and Structures of Authority in Medieval Nishapur," IJMES 26.3 (August 1994), pp. 427-42.

L. Marlow, Counsel for Kings: Wisdom and Politics in Tenth-Century Iran, vol. 1, The Nașihat al-mulūk of Pseudo-Māwardī: Contexts and Themes, Edinburgh, 2016.

C. Martindale, "Introduction: Thinking Through Reception," in C. Martindale and R. F. Thomas, eds., Classics and the Uses of Reception, Malden, Mass./Oxford, 2006, pp. 1-13.

C. Martindale, "Reception," in C. W. Kallendorf, ed., A Companion to the Classical Tradition, Malden, Mass., 2010, pp. 297-311.

J. S. Meisami, "Genesis of Court Literature," in J. T. P. de Bruijn, ed., A History of Persian Literature, vol. 1, General Introduction to Persian Literature, London/New York, 2009, pp. $233-268$.

A. Rajāìi, Farhang-e ash'ār-e Hāfez: Sharh-e mostalahāt-e Sufi-ye divān-e Hāfez, 2nd ed., Tehran, 1985 .

J. C. Reeves, Prolegomena to a History of Islamicate Manichaeism, London/Oakville, Conn., 2011.

J. C. Reeves, "Jacob of Edessa and the Manichaean Book of Giants?," in M. Goff, L. T. Stuckenbruck, and E. Morano, eds., Ancient Tales of Giants from Qumran and Turfan: Contexts, Traditions, and Influences, Tübingen, 2016, pp. 199-211.

H. Ritter, "Einführung in die Edition," in H. Ritter, ed., Ilahi-nama die Gespräche des Königs mit seinen sechs Söhnen: eine mytstiche Dichtung von Farīdaddīn 'Atțār, and ed., Tus, 1989, pp. $5^{-15}$.

H. Ritter, Das Meer der Seele: Mensch, Welt und Gott in den Geschichten des Fariduddin 'Aìdu, tr. J. O'Kane as The Ocean of the Soul: Men, the World, and God in the Stories of Farìd al-Dìn Aìn n, Handbook of Oriental studies 69, Leiden/Boston, 2003.

W. C. Rowatt, F. Lewis, and M. Cotton, "Patterns and Personality Correlates of Implicit and Explicit Attitudes Toward Christians and Muslims," Journal for the Scientific Study of Religion 44.1 (March 2005), pp. 29-43.

J. Rubanovich, "Orality in Medieval Persian Literature," in K. Reichl, ed., Medieval Oral Literature, Berlin/Boston, 2011, pp. 653-79.

J. Rubanovich, ed., Orality and Textuality in the Iranian World: Patterns of Interaction across the Centuries, Jerusalem studies in religion and culture 19, Leiden, 2015.

M.-R. Shafíi-Kadkani, Zabān-e she'r dar nașr-e Sufiyya: Dar-āmadi beh sabk-shenāsi-ye negāh-e 'erfāni, Tehran, 1988.

M.-R. Shafi i-Kadkani, "Introduction,” in F.-D. 'Ațțār, Elāhināma, 3rd ed., Tehran, 2013, pp. 29-108. 
S. Shaked, "From Iran to Islam: Notes on Some Themes in Transmission," Jerusalem Studies in Arabic and Islam 4 (1984), pp. 31-67.

T. Smith, "Recognitions of Clement," in A. Roberts, J. Donaldson, and C. Coxe, eds., From Ante-Nicene Fathers: Translations of the Writings of the Fathers down to ad 325, vol. 8, The Twelve Patriarchs, Excerpts and Epistels, the Clementina, Apocrypha, Decretals, Memoirs of Edessa and Syriac Documents, Remains of the First Ages, Buffalo, 1886; online: http://www.newadvent.org/fathers/0804.htm (accessed: o1 March 2018).

J. T. Walker, The Legend of Mar Qardagh: Narrative and Christian Heroism in Late Antique Iraq, Berkeley/Los Angeles/London, 2006.

K. S. Whetter, Understanding Genre and Medieval Romance, Aldershot, Hampshire/ Burlington, 2008.

N. Yavari, "Mirrors for Princes or a Hall of Mirrors? Nizāam al-Mulk's Siyar al-Mulūk Reconsidered," al-Masaq 20.1 (March 2008), pp. 47-69. 